\title{
Queering the Art Classroom: Queering Matters
}

\section{Tabitha Verity Patience Millett}

\begin{abstract}
Since 2003, successive British governments have taken steps to develop legislation supporting lesbian, gay, bisexual, transgender, questioning / queer, intersex, asexual and those who are gender / sexuality non-conforming more generally (LGBTQIA+). In doing so, they have foregrounded the need for educational institutions to respond proactively to this legislation. There is evidence to suggest that homophobia is prominent in UK schools, yet measures to address the issue have largely rested on schools and LGBTQIA+ charities, reducing discussions of homosexuality to anti-bullying discourses and introducing curriculum modifications that are overwhelmingly homonormative. The limitations of these current approaches ignore the societal and institutional power structures that help to produce homophobia, which is often referred to as heteronormativity. Drawing on aspects of new materialist and queer theoretical perspectives, this article follows the findings of a research project that focused on developing an intervention at GCSE level, exploring non-normative genders and sexualities in the art curriculum. The research project was based on a class in a secondary school in North London from 2017 to 2018. Through the application of a pedagogy rooted in queer theory, the study explores the possibilities of disrupting heteronormativity and didactic learning by investigating student responses to the interventions. For this article, I focus on one student's artwork and her reactions to the process of making her artworks during the project. As such, the study is an exploration of an attempt at moving beyond the homonormative inclusion of LGBTQIA+ content, towards a deeper exploration of gender and sexuality within the curriculum cultivated through making.
\end{abstract}

\section{Keywords}

queer theory, new materialism, LGBTQIA, art, diversity, education

\section{Introduction}

In my time as an art teacher, I have encountered several schools producing innova-tive and progressive work at key stage 3-5, however these practices continue to be outlier rather than the norm. Many reputable art education scholars have 
criticised the limited approaches that schools adopt to art practice and learning (Addison \& Burgess 2012; Atkinson 2011, 2017). This is often because school-based approaches to art tend to rely on aesthetic judgements which underpin for-malist and representational agendas to teach art practice to learners (Atkinson 2011, 2017). For example, many art teachers still favour dead white European male painters when giving students examples from which to draw inspiration and develop technical skills. This practice reproduces invariable pastiches, such as 'my David Hockney portrait' seen in OCR's most recent GCSE exemplar material, avail-able on their website (OCR 2019). Even popular GCSE topics such as 'identity' lar-gely rest on multiculturalist and humanist concepts, where students are encouraged to represent their identity in the form of Western portraiture, by high-lighting visible differences, be it race, religion or gender (Atkinson 2011). This seemingly celebratory model of supposed individuality if often coupled with the modernist notion of artistic self-expression, with its association with originality and authenticity. However, such an approach avoids critical discussion with regards to social construction and fluidity of the self, relying instead on essentialist signifiers that act as the primary indicators for identity (Addison 2007; Atkinson 2011).

The normalisation of these practices in schools is located in schemes of work and associated assessment frameworks. For the GCSE, there are four objectives that tend to cultivate a particular linear way of art practice (Atkinson 2011). For example, the first objective is often interpreted by art teachers as observational drawing. The second objective, to 'experiment' with the appropriate media, usually consisting of charcoal and oil pastels. The third, is to be able to link the work to an artist and then the fourth, a 'personal response', drawing together all four objec-tives (Atkinson 2011). This process of making artwork largely takes place in an A4 or A3 sketchbook and rarely deviates outside of the books; due to this restraint, the work produced is mostly two-dimensional. The majority of the artwork in the books are often carbon copies of each other, with student work mainly being dif-ferentiated through the assessment objectives. The reproduction of this practice is furthermore supported by examination boards who present booklets to examiners conveying what certain grades should look like, or worse, art teachers presenting last year's GCSE sketchbooks that received high marks. The prescriptive nature of art practice in schools dominates the GCSE and A level projects and in turn pro-duces certain types of teacher and learner subjectivities, recognisable in descrip-tions of neoliberal education (Ball 2013). What is then pushed aside within this matrix of performance and conforming to assessment objectives is the nurturing of different pedagogies and individual idiosyncrasies that may open spaces for new becomings that do not fit a pre-existing framework (Atkinson 2011).

If the current art curriculum produces particular learner and teacher subjectiv-ities that are restrictive in terms of opening new ontological spaces, the same can be said for school approaches to gender and sexuality. Although there is innovative work being done in schools in Wales by researchers who have disrupted gender /sexual norms through artbased practices (Renold \& Ringrose 2017), they are not specifically focused on the art curriculum, and for the majority of schools in the UK, exploring gender and sexuality tends to be rare. Conservative social discourses of corruption to childhood innocence (Edelman 2004) create anxiety around the issue, as evidenced in the recent actions by parents in Birmingham, who removed their children from Parkfield Community School as they protested against the newly reformed Children and Social Work Act 2017, which made teaching lessons on same-sex relationships mandatory for all schools. Their action resulted in the 
headmistress' decision to suspend the lessons. Actions such as these are problem-atic, as they can intensify discourses that deny students a sexuality and support beliefs that children are only safe within a culture of heterosexuality (Edelman 2004). This line of thinking overlooks the ubiquity of gender and sexuality present in student and staff lives. This example is a good illustration of the way contempo-rary discourse in schools is closing down, rather than opening up, ontological spaces for the exploration of gender/ sexuality in schools.

This discursive closure is also illustrated in attempts to increase visibility of LGBTQIA+ people in the curriculum, where heteronormativity ${ }^{1}$ tends to still be supported by 'homonormativity' (Duggan'2002), as resources centre around gay celebri-ties and gender-conforming married couples like Tom Daily and Ellen DeGeneres. The essentialist representation of the 'good gay' creates an environment where heterosexual norms, such as monogamy / child rearing / gender conformity, are something to aspire to, excluding LGBTQIA+ students who may not want to, or do not, conform in such normative ways. In response to this, my project explores the possibility of 'queering' the curriculum, which means addressing its inherent normativity and construction of normativity by cultivating spaces of becoming.

\section{From queering pedagogy to queering matters Part 1}

The questions arising so far from this article are: how do we approach gender and sexuality in different ways with students? How do we include those who fall outside the heteronorms without supporting essentialist discourses? And how can this be done through the art curriculum without reproducing the same art practices / discourses, and leaving spaces for new becomings?

Dennis Atkinson $(2011,2015,2017)$ has written widely on pedagogies of the 'notknown', which encourage and respond to the different ways students learn outside of prescriptive and established models. Using Atkinson's (2011, 2015, 2017) pedagogy of the 'not-known', perhaps an alternative model to the reproduc-tion of school norms, be it established art knowledges / practices, heteronormativ-ity / homonormativity and LGBTQIA+ resources, could be a way to cultivate spaces of the unknown, the un-coded and the queer in a bid to reconfigure the space and to create events of becoming. Borrowing from New Materialist approaches, however, the term 'pedagogy' may be too anthropocentric, as it sug-gests that subjects - students and teachers, and objects established curriculum knowledges, are separate entities constituted by human interaction alone. Rachel Jones $(2009$, 6), for example, has developed the concept of 'material intelligence' within art practice, arguing:

Material intelligence would then belong neither wholly to human beings nor to matter but would emerge in the space between them. It is in this space between perhaps - where an acceptance of not knowing allows human intelligence about matter to be coupled with the guiding intelligence of matter

- that the creative practices of art and thought can take place.

Hence, we need to start addressing all matter, non-human and human, if we are to start thinking of reconfiguring normative processes and anthropocentrism in education, what I call 'queering matters'. Karen Barad (2003), a major new materi-alist theorist, proposes taking Judith Butler's (1990) performativity beyond its 
delimited anthropomorphic and iterative linguistic citations towards a performativ-ity which includes non-human and human matter or a 'posthuman performativity'. For Barad (2003), there is no separation between subject and object, only the understanding that all matter is constituted through immanent entangled ongoing 'intra-actions'. 'Intra-action' being different from 'inter-action' as 'inter-action' sug-gests two separate objects colliding and therefore pre-existing the collision. Whereas in 'intra-action', the phenomena do not pre-exist the collision or intra-ac-tion. This process of immanent intraaction between the material-discursive /human and non-human, produce a series of intense affects that themselves affect and are affected (Massumi 2015). For instance, affects could be described as moments of effects upon another body / matter, and vice versa, that are beyond language or meaning (Massumi 2015). This is not to say that language does not produce certain affects too, but the effects of language are heavily coded in pre-established representational signifiers whereas, affects, for Brian Massumi (2015), coincide momentarily with experience. Yet, the dilemma of affects is that they can only be understood through language / signifiers. The notion of affect relations between all matter constituting phenomena dissolves boundaries of human and nonhuman matter, suggesting that, for example, art practice or heteronormativity is neither human nor non-human but, Jones posits, 'emerge(s) in the space between', by becoming together or 'to affect and be affected' (Massumi 2015, ix). It is this relationality of affects amongst matter where rupture can occur to pro-duce events of becoming and transformations.

However, not all affects between matter produce a change in state / a becom-ing, some affects reproduce norms and order. Drawing on Deleuze \& Guattari (1994), it is art and the artistic process where radical deconstruction of these norms, or 'territorialising lines', can rupture or 'deterritorialise' norms, generating a pure event of becoming. For them, art 'is the language of sensation(s)' that can cre-ate new worlds, new visions or 'blocs of sensation' (Deleuze \& Guattari 1994, 176). Artists, then, for Deleuze \& Guattari $(1994,175)$, are the 'inventors and cre-ators of affects' that 'make us become with them'. Even though their notion is, for me, too anthropocentric, suggesting the artist is the prime mover of affects, it still hints that art practice 'makes us become with them', perhaps referring to a collec-tive entanglement of matter, human and non-human to produce becomings. Here then, the potential art practice has for creating 'blocs of sensation', 'new worlds' or rupture, is due to its experimental nature, as only through experimentation can we enter into the realms of queerness and the unknown, leading to different becom-ings. Deleuze \& Guattari $(1994,111)$ remark on the quality of experimentation to cultivate changes in state:

To think is to experiment, but experimentation is always that which is the process of coming about - the new, remarkable, and the interesting that replace the appearance of the truth and are more demanding than it is. What is in the process of coming about is no more what ends than what begins.

This quotation would suggest, in the context of art in schools, that troubling the aesthetics of representation and prescriptiveness and exchanging it for a prac-tice of affects, experimentation and indeterminate unfolding, may nurture 'the pro-cess of coming about-a new'. Thus, instead of pre-established practices, such as portraiture for the topic 'identity' or teaching students the struggles of LGBTQ life, the process of intra-acting through experimentation, that is, nothing exists pre- 
collision but is experienced immanently through affects, leaves an unknown posi-tion, opening space for reconfiguration or of 'queering matters'.

\section{Queering matters Part 2: Methodology / intervention}

But how can this openness and experimentation be achieved in a GCSE art class when students' work still needs to be recognised within the assessment criteria /by an examiner? Can a more experimental practice - a queering of matters - be explored without reinforcing essentialisms when it comes to gender and sexuality?

These questions cannot be answered with one research intervention. However, by scaffolding the students' experimentations and working outside the figurative form by focusing more on materials and processes, I believe I was able to deviate from previous prescriptive and formalistic models and essentialist LGBTQIA+ narratives.

Whilst many agree that sexuality should be explored in art education (Stanley 2007; Addison 2012), how it should be utilised in the art and design curriculum is still debated. Of course, there is no singular way to explore gender and sexuality, but troubling normativity might be a good starting point. Yet, as noted, some pro-posals made by art educational researchers who are invested in LGBTQIA+ or gender and sexuality subjects have tended to underscore essentialist practices as they have rested on presenting positive LGBTQIA+ 'countertypes' and 'themes' (Ashburn 2007; Chung 2007). Some propose that LGBTQIA+ topics may be bene-ficial in the art classroom as students could explore the 'outsider perspective' and LGBTQIA+ themes such as 'coming out' or 'depicting fear' (Stanley 2007, 7). How-ever, presenting LGBTQIA+ themed artwork as the 'outsider perspective' or as an 'alternative knowledge' may reinforce hierarchical relationships between the norm and the other, leaving students with distorted perceptions of LGBTQIA+ people and conventional portrayals.

Researchers have also suggested that teachers need to affirm LGBTQIA+ stu-dents' identities by acknowledging LGBTQIA+ art histories (Stanley 2007; Walker 2007). This, they believe, would not only expand the curriculum but would provide LGBTQIA+ students with resources and a sense of tradition. However, the canon of artwork considered LGBTQIA+ presents very particular representations of LGBTQIA+ people with recurrent themes, such as depicting sexuality in figurative representations and explicit iconography of same-sex erotic acts, AIDS references and gender bending, to present a unified visible identity (Getsy 2015). The restric-tion to the human form can also be problematic as the body is 'inescapably cultur-ally marked', due to society categorising the form according to the sex then projecting cultural assumptions based on the form, known as gender (Getsy \& Sim-mons 2015, 43). From here, identities are made legible and therefore can be easily regulated through dimorphisms; male / female, gay / straight. Presenting artwork to students and labelling it 'LGBTQIA+ artwork' or categorising it as an example of 'gay aesthetics' (Ashburn 2007, 33), can serve to essentialise people and their artistic contributions. The idea put forth by researchers that LGBTQIA+ artwork can validate LGBTQIA+ youth identities is problematic as it excludes identities that exist outside of the prescribed examples / themes. Hence, there is a dilemma that presenting artwork that has LGBTQIA+ identities depicted in the content as exam-ples could lead to tokenism and essentialism.

Undeniably, it is difficult to capture sexuality, desire and gender in a visibly sophisticated way as sexuality and gender are complex and fluid, but reducing 
sexuality or difference to recognisable depictions, such as gender bending / same sex coupling as previously discussed, restricts sexuality to figurative representa-tions leading to categories of regulation (Getsy \& Simmons 2015). Thus, in the intervention I produced artwork with students that 'resist(ed) the reproduction of regulatory power that makes the queer subject identifiable and distinguishable' by refusing intelligible representations (Getsy \& Simmons 2015, 43). In line with the work of Jack Halberstam (2005) and David Getsy (2015), the intervention exam-ined the possibilities of investigating and creating non-representational artwork with students, in the hope that this may move beyond the restrictions of bodily /figurative representational artwork towards more dynamic queer and unknown interpretations. I apply the term 'non-representational' here to refer to objects /images / art that do not accurately depict a material object. Getsy (2015) proposes abstraction as having potential for queerness, as non-representational objects /depictions produce less-determined ways of seeing bodies and identities. He sug-gests that ambiguity may dissolve binaries and categories by resisting bodily con-figurations, as abstraction, like queerness, is not easily readable or restricted to one interpretation. Both Halberstam (2005) and Getsy (2015) have suggested that the materials and processes within the artwork may evoke the complexities of sub-jectivity instead of a representational subject / sign. Halberstam (2005) and Getsy \& Simmons (2015) view abstraction as expanding new possibilities for understand-ing accounts of gender plurality and non-normative sexualities that transcend the body, whilst seeing the political potential of refusing representation.

Thus the intervention focused on the materials and processes, consisting of the students being presented with non-representational artwork. There are count-less examples of artwork that evoke ambiguous modes of being, but for one of the interventions the class and teacher looked at the work of Eve Hesse and Ruth Hardinger. The selected pieces had no intended association with gender and sexu-ality, and students were asked to read gender and sexuality into the work. This allowed students to explore gender and sexuality outside of recognisable images/depictions, relocating sexuality outside the figurative form. The students were asked to collect everyday objects and investigate the materials, the forms and the social discourses surrounding the objects with a heteronormative lens. For exam-ple, social discourse $=$ lipstick $=$ feminine, material $=$ metal $=$ masculine , form $=$ curve $=$ feminine. The task of collecting everyday objects drew attention to heteronormativity in the everyday. The students were then asked to think through breaking and puncturing these heteronormative associations using their art practice by experimenting with materials and processes in any material of their choos-ing making sure they worked outside their books, a rare occurrence due to the structuring of schemes of work in accordance with assessment criteria. This making process lasted up to 4-6 weeks. There was little prescriptiveness in what we wanted the students to do, only to have them experiment with the materials and processes to create something outside of representation / association.

Drawing upon research conducted in a North London co-ed comprehensive school which focused on a class of year 10, GCSE art students (ages 14-15) who, for one unit of coursework, explored the topics of gender and sexuality, the follow-ing data excerpts examine one student's interviews and artworks. The data excerpts also include the teacher's interview and focus groups, all concerning the same student. The data-collection methods used for this study were, one-to-one semistructured interviews with the students and the class teacher, focus groups with the whole class, audio recorded lessons and the documentation of the 
artwork. Below, I will examine both the operations of intra-acting and queering matters which may hold potential for reconfiguration of the self / becoming and new imaginings for queering the art classroom.

\section{Viviana's becoming}

At the beginning of the GCSE unit focusing on 'gender and sexuality', I conducted focus groups with the class to collect and understanding of their thoughts and feel-ings regarding subjects such as, sexism, gender conformity and LGBTQIA+. In one of the focus groups a girl called Viviana, agreed with a girl called Oman that 'com-ing out' as gay is 'fashionable and trendy at the moment' and that 'a lot of people are jumping on the bandwagon'. Daphne Patai (1992) would describe comments such as these as having 'surplus visibility', where the presence of the minority, who have previously been invisible, now are visible, causing an effect of excessiveness compared to the already normalised majority. In this context, the heteronormativity of the school goes unnoticed by Oman and Vivianna as this is not seen as exces-sive compared to being gay. Interestingly, Oman and Viviana's comments also to an extent mirror Foucault's $(1984,163)$ concept of sexuality, as 'sexuality is something that we ourselves create-it is our own creation', meaning the more we speak sex-ual identities into existence, the more we create, the more we become. In this case, perhaps a greater number of students could be identifying outside the heterosexual norm, as non-conforming gender and sexuality topics are more spo-ken about within contemporary discourse.

For a section of the project, students were asked to work collaboratively, thinking through breaking heteronormative connotations through experimenting with materials and processes. For example, students used their everyday objects based on the material and social heteronormative associations and created sculp-tures to obscure or queer these associations. Below is an excerpt from the one-to-one interview I had with Viviana about making her sculpture with a boy called Marlin (see Figure 1):

Tabitha: 'What was the idea behind your final sculpture with Marlin because you said it was a mixture?'.

Viviana: So, there's this one section where there's cardboard and Modroc over it but the cardboard got wet (see Figure 2). So, the Modroc in it like folded and creased. And you can say that was a happy accident 'coz we didn't intend for that to happen we wanted it to be a flat surface. But once the imperfection happened once, we saw that the water like kind of not melted but kind of, you know. The structure of it like was compromised. So, it like fell down and it drooped, and it created a different surface, like the ridges and bumps. It created a different sha-dow and it made the piece that little bit better 'coz you know it was just that little difference the imperfection which actually improved the sculpture to the point where like you can see the detail and like from where the Modroc dries, it's almost falling off and just the little pieces like that, that change it.

Returning to Barad (2003), agency is relational in nature, as agency is not owned by an individual subject but instead exists within the affective relational practices between matter. We can see the agency of matter and its affective 


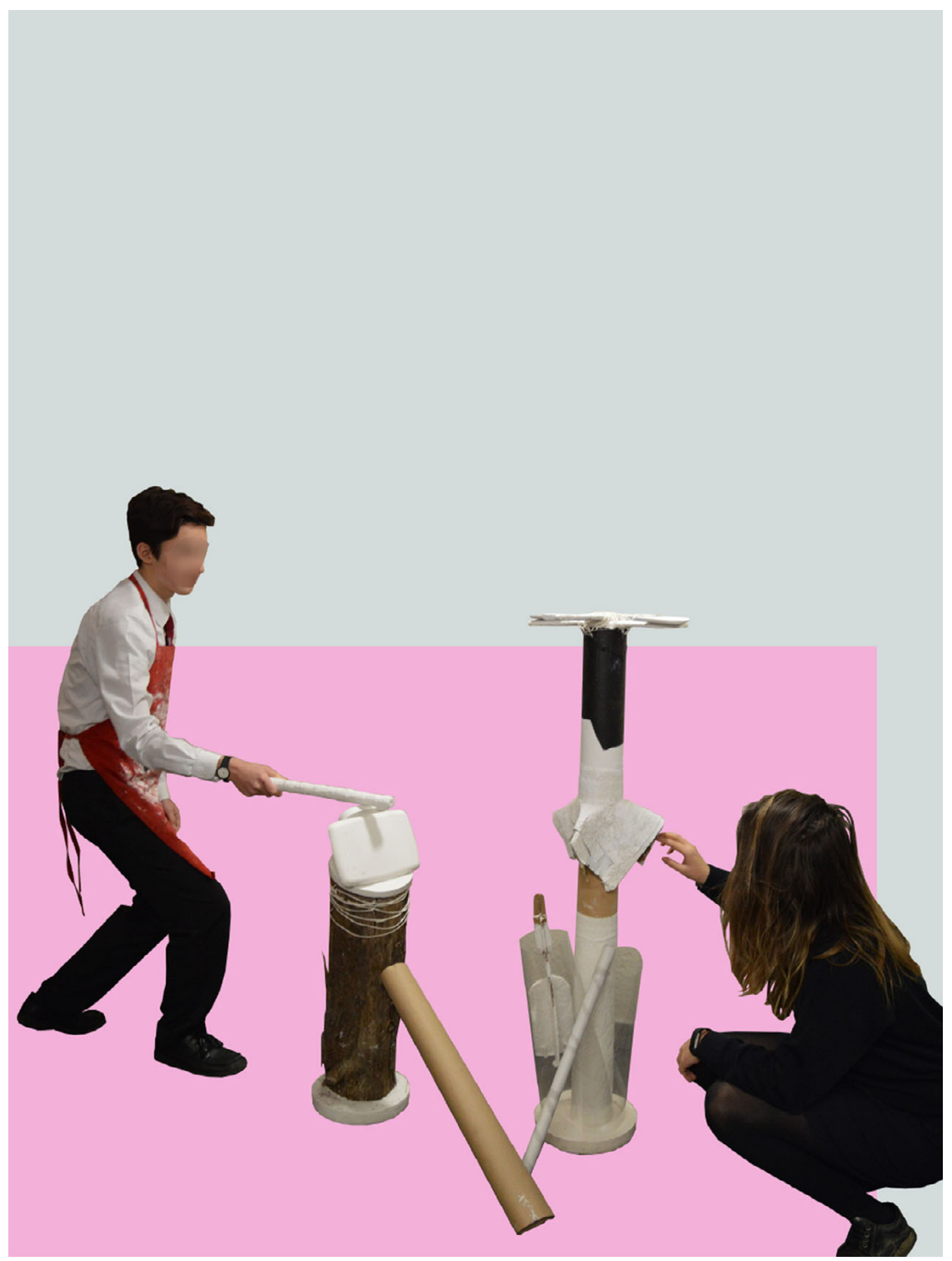

Figure 1

Marlin and Viviana's collaborative sculpture work

relations, with Viviana's 'happy accident'. Just as Rachel Jones' (2009) suggests, the 'happy accident' echoes the unknown, the un-coded and queer space, as Viviana lets go of knowing, intentionality and perfection. Instead, Viviana begins to realise the material's agency as something positive and happy allowing it to do what it wants. Here, the matter fighting back, the Modroc's 'intelligence', was the event that reconfigured the space and guided Viviana to think in different ways, to 'emerge in the space between' - to become with the matter. She was the affect and she was affected. The experimental nature of this part of the project enabled the materials and processes to affect Viviana and vice versa. The interview continues: 


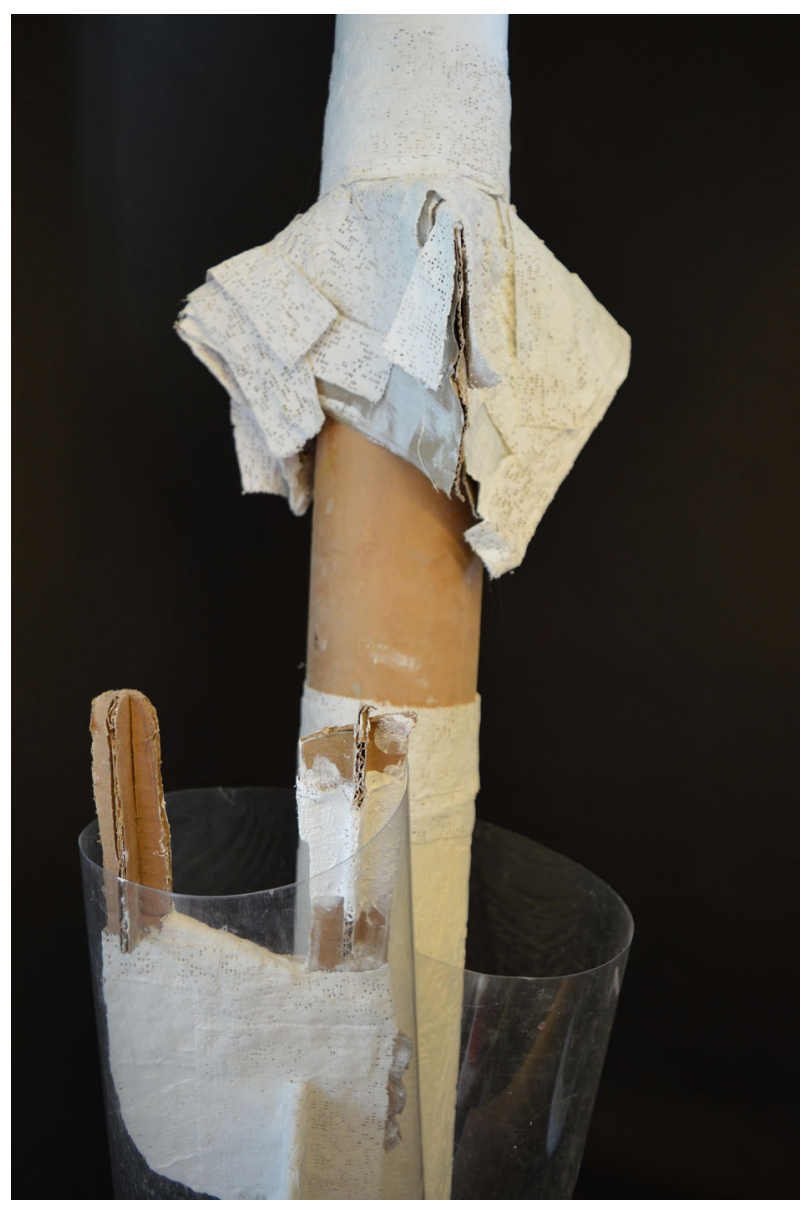

Figure 2

The Modroc fold to which Viviana is referring

Tabitha: So these, these imperfections as you like to call them that are bringing out different effects in the sculpture. Are you, can you see a link between gender and sexuality, or can't you?

Viviana: So I'm not sure but like maybe how you intend things to be how you, you know. How you intend things to be when it doesn't happen, how it's not necessarily a bad thing how's it, it can like be good like the. I don't know how to phrase this but like. So, you see like in real life and in gender and sexuality how if you want it to be one way and that one way doesn't happen it's not always a bad thing. Its good in most cases when it's not the norm. Or what you wanted it to be.

Tabitha: And I guess creating something new?

Viviana: Yeah. Creating something new.

In the excerpt above, it would seem as though the entanglement of matter Viviana,materials and processes - may have reconfigured Viviana's thoughts 
towards gender and sexuality. Instead of Viviana feeling as though 'coming out' as gay is just 'jumping on the bandwagon', her earlier thinking, four months prior, is replaced with the idea of creating something new out of difference. The intended placement of the Modroc and its agency pushing back, enabled Viviana to see a new possibility, what Deleuze \& Guattari $(1994,11)$ postulate as 'the process of coming about is no more what ends than what begins'. This sentiment was made even more evident when Viviana, in her next sculptural work after her collaborative work with Marlin, decided to continue with the idea of material and its processes creating new potentials.

During the making lessons, I would catch Viviana running about the classroom, mixing up plaster, covered in powder, not talking to anyone, just completely in the zone. I would go over occasionally to ask if she was OK and so did the class teacher. Yet, whenever I went over to her, she would just assure me that she was fine and say, 'I'm just going for it, not sure what I'm doing but I'm just going for it and seeing what happens.' Viviana's 'acceptance of not knowing' (Jones 2009, 6) allowed for the process of intraacting through experimentation, as nothing existed pre-collision. For instance, Viviana did not have a defined outcome or a particular established knowl-edge she wanted to exercise. Instead, Viviana let go and allowed herself and the matter to experience the immanence of affects by working together. The warmth of her hands mixing with the plaster, the plaster warming and cooling as she placed cardboard within it, the wax sticking to the Modroc and it slipping with her hands, these were all moment of intra-active becomings. Not only was the material entering into unknown spaces but so was Viviana, here we can see a queering of all matters. This was reiterated through Vivana's idea of repetition:

Tabitha: And then why did you repeat the forms?

Viviana: I repeated the forms so that I would get mistakes, so that I can get new ideas and I can see what I could have done So, umm, if doesn't work then you can find a new way to do it. And then you can use a new material, you can try umm try to make that material work or pair it with something else so that it works.

Tabitha: And then how are you seeing, are you seeing process as linking to gender and sexuality or identity?

Viviana: Yeah because it's never a static thing, because umm, with my process I developed overtime, so my first stump and my last stump they are very dif-ferent. And that relates to like a person, you're not the same person a year ago, or several years ago or last week, so you're constantly changing, you're never static.

The excerpt is reminiscent of Jack Halberstam's (2011) theory of queer failure, where conventional understandings of success, namely heteronormative - much like the happy gender-conforming gay celebrities on LGBTQIA+ display boards in schools exclude others who do not conform in such ways. Thus, Halberstam (2011) exchanges the view of nonconformity to heteronorms as a failure, with the idea that failure creates new paths of being, that too can be successful. For exam-ple, the 'stability' of gender and sexuality is as a result of its iterative nature, as norms are upheld by individuals in order to be recognised as viable subjects, femi-ninity = women. Yet due to the iterative nature of the norms, stability is in fact a 
fallacy, as the norms are always open to slippage, rupture and failure. Here, Vivi-ana's art work, where repetition is so important, shows that things 'failing' is not necessarily a problem. Viviana is relating this failure to gender and sexuality - by seeming to suggest that gender and sexuality diversity is also the result of repeti-tion, failure and new ideas which defeat the norm and creates something new. Vivi-ana's understanding shifted from 'jumping on the band wagon', a more pejorative reading of gender and sexuality, to a more fluid understanding - 'you're never sta-tic', just like Viviana's experimentations.

We can see clearly from Viviana's voice over and video (see Figure 3), that she was subsumed in the ideas of repetition, material agency and process. Viviana filmed the process of the work to capture these moments of intra-acting with materials, the ongoing making, the 'constantly changing'. Applying Getsy (2015) thinking, Viviana's work evokes a site of in-betweenness as her work rests outside of representation and definitive description (see Figure 4). The work, a mixture of plaster and cardboard, captures a hybridity of something and nothing, an incom-pleteness and a completed, it is both rough and smooth, fragile and hard, recognisable but confusing. If we seek to find gender or sexuality in Vivianna's sculptures, it may be limiting to suggest only looking for male or female, gay /straight classifications, as any categories fixed to the work do not do the work jus-tice. This is because there is no logic to the sculptural forms, no final destination or linear order, just continual states of becoming something, but nothing. In Vivi-ana's video work and with her presentation of the buckets she used, we can account for her capturing the process of formation itself. Viviana's 'stumps' remind me that we are all continually becoming something throughout our lives and that we are all in a constant process of formation and flux. Therefore, when investigat-ing Viviana's work, we can see the potential for considering a wider range of pos-sibilities for genders and sexualities that speak beyond binaries and static

(a)

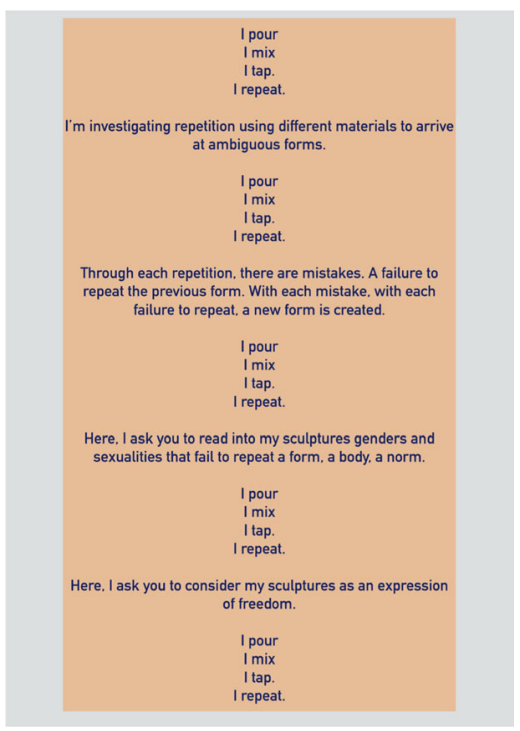

(b)

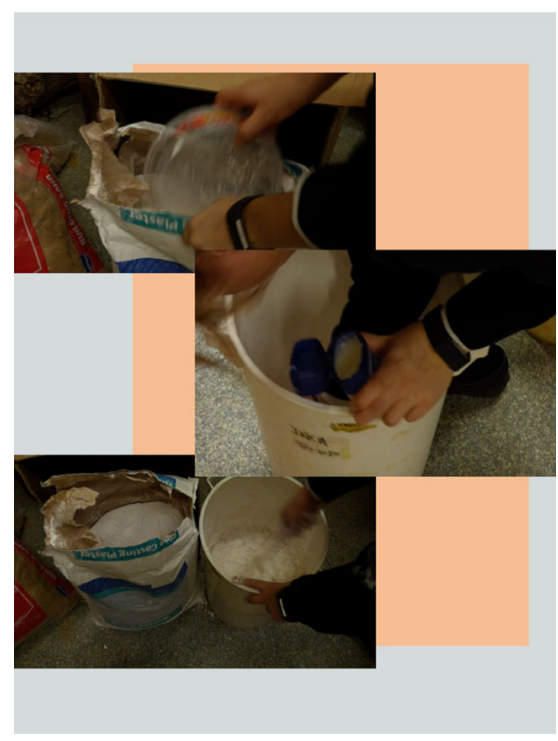

\section{Figure 3}

Viviana's voice over (A) and snap shot of her video (B) 


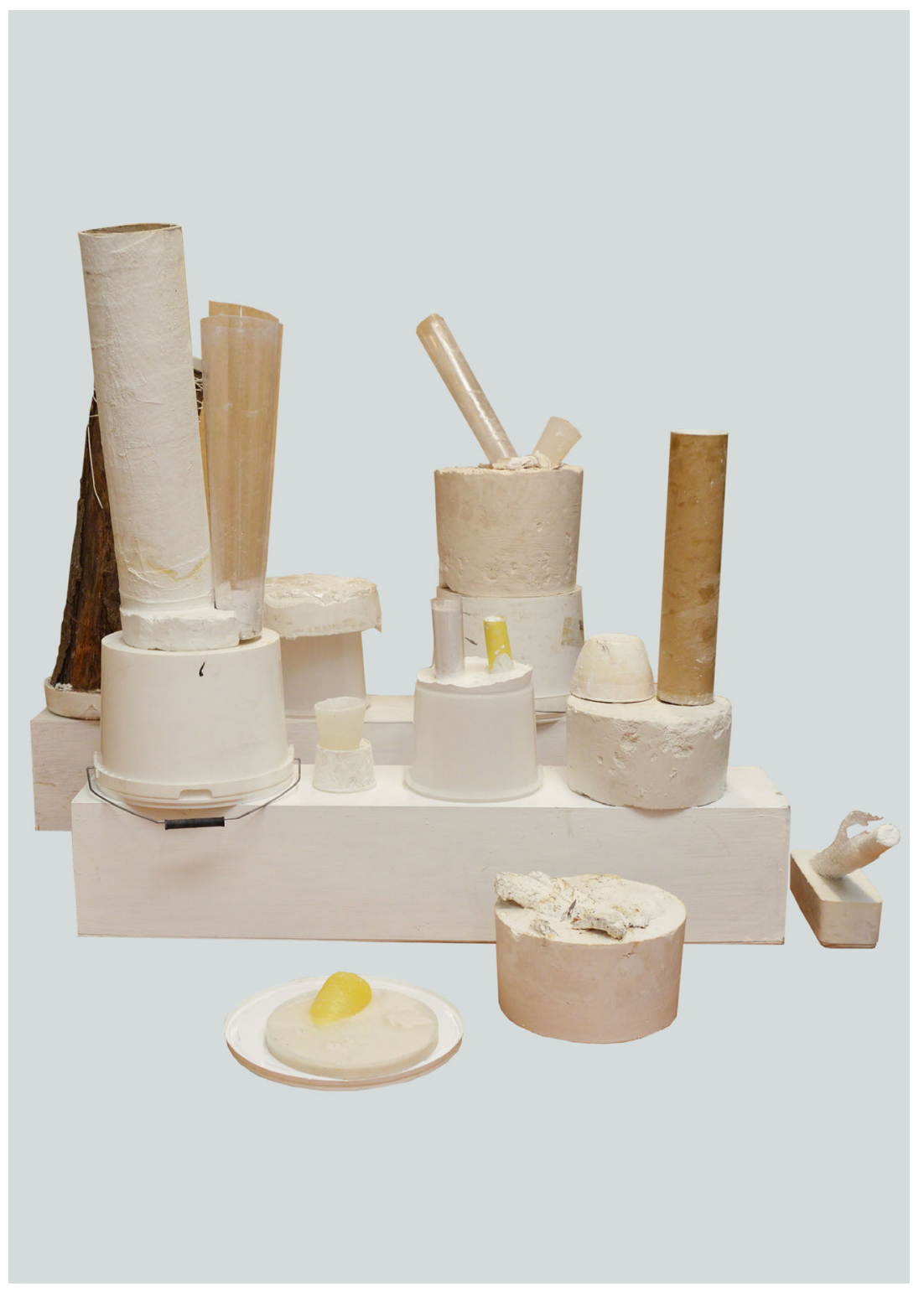

Figure 4

Viviana's sculpture

categories or even the human. The ambiguity in the artworks tells me that there are no answers or essential truths, just continual interpretations and readings (Getsy 2015).

\section{Queering matters conclusion}

Art 'is not a way of explaining the world; it is a way of coming to know the world, more specifically, a world that does not yet exist' (Richardson 2017, 95). 
This article has explored different ways of thinking about the implementation of gender and sexuality within the curriculum through making. The article aims to not criticise the work carried out by LGBTQIA+ charities in schools, but rather wants to think through cultivating queer sites outside of bullying and victim dis-courses that only serve to reinforce heteronormativity. The cultivation of queer sites is not only to discuss troubling heteronormativity in schools but to look for alternatives in school art practice. It was through making that this GCSE student was able to think differently about gender and sexuality. The materials and pro-cesses of the work guided her to become, to change in state. Therefore, the focus of analysis is not on the final object per se but on the process of intra-action in the creation of the work which transforms the human and non-human - a 'queer-ing of matters'. Interestingly, the class teacher had told me towards the end of the project that Viviana 'was stressing about her sketch book saying "it's not, every page isn't nicely titled". It is here we see the disconnect between learning to con-form and learning to become in 'a world that does not yet exist'.

Tabitha Millett is an Affiliated lecturer on the Art and Design PGCE and Art, Culture and Education MPhil at Cambridge University. She researches in the areas of queer theory, new materialism and art education at University College London, Institute of Education. Tabitha's PhD research focuses on developing and troubling the art curriculum at GCSE through exploring the topics of gender and sexuality. Tabitha has taught art and design in a number of London schools and contin-ues to develop her own artistic practice working with the theme of queering. Tabitha is also director of Queering the Art Classroom, a small non-profit organisation working with the National Trust to exhibit school students' artwork investigating gender and sexuality. Tabitha has held exhibitions at the National Trust, Dean Street Soho, The Oxford International Women's Festival, Brick Lane, Roman road and Hackney Road. Contact address: University Cambridge, Faculty of Education, Hills Road, Cambridge.

Email: tvpm2@cam.ac.uk

\section{Notes}

1. The term 'heteronormativity' was devel-oped by queer theorist Gayle Rubin (1993) and is often described as the hegemonic social system that constructs heterosexuality as natural and superior to other sexualities, such as homosexuality.

\section{References}

Addison, N. (2007) Identity politics and the queering of art education: inclusion and the confessional route to salvation, International Journal of Art \& Design Education, Vol. 26, No. 1, pp. 10-20.

Addison, N. (2012) Fallen angel: making a space for queer identities in schools, International Journal of Inclusive Education, Vol. 16, No. 5-6, pp. 1-16.
Addison, N. \& Burgess, L. (2012) Debates in Art and Design Education. London: Routledge.

Ashburn, L. (2007) Photography in pink classrooms, International Journal of Art \& Design Education, Vol. 26, No. 1, pp. 31-8.

Atkinson, D. (2011) Art, Equality and Learning Pedagogies Against the State. Rotterdam: Sense. 
Atkinson, D. (2015) The adventure of pedagogy, learning and the not-known, Subjectivity, Vol. 8, No. 1, pp. 43-56.

Atkinson, D. (2017) What is art education, what might it become? in J. Jagodzinski [Ed.] What is Art Education? New York: Springer Nature, pp. 143-60.

Ball, S. J. (2013) Foucault, Power, and Education. New York and London: Routledge.

Barad, K. (2003) Posthumanist performativity: toward an understanding of how matter comes to matter, Signs: Journal of Women in Culture and Society, Vol. 28, No. 3, pp. 801-31.

Butler, J. (1990) Gender Trouble: Feminism and the Subversion of Identity. New York: Routledge.

Chung, S. K. (2007) Media literacy art education: deconstructing lesbian and gay stereotypes in the media, International Journal of Art \& Design Education, Vol. 26, No. 1, pp. 98-107.

Deleuze, G. \& Guattari, F. (1994) What is Philosophy? Columbia: Columbia University Press.

Duggan, L. (2002) The new homonormativity: the sexual politics of neoliberalism, in R. Castronovo and D. D. Nelson [Eds] Materializing Democracy: Toward a Revitalized Cultural Politics. Durham, NC: Duke University Press, pp. 175-94.

Edelman, L. (2004) No Future: Queer Theory and the Death Drive. Durham, NC: Duke University Press.

Foucault, M. (1984) 'Sex, power, and the politics of identity', interview by Bob Gallagher and Andrew Wilson, in P. Rabinow [Ed.] Ethics: Subjectivity and Truth. London: Allen Lane, pp. 164-73.

Getsy, D. J. (2015) Abstract Bodies: Sixties Sculpture in the Expanded Field of Gender. New Haven: Yale University Press.

Getsy, D. \& Simmons, W. J. (2015) Appearing differently: abstraction's transgender and queer capacities, in C. Erharter, D. Schwarzler, R. Sircar \& H.
Scheirl [Eds] Pink Labour in Golden Streets: Queer Art Practices. Berlin: Sternberg Press and Vienna Fine Arts Academy, pp. 39-55.

Halberstam, J. (2005) In a Queer Time and Place: Transgender Bodies, Subcultural Lives. New York: New York University Press.

Halberstam, J. (2011) Queer Art of Failure. Durham, NC: Duke University Press.

Jones, R. (2009) On the Value of Not Knowing: Wonder, Beginning Again and Letting Be (online). Available at: www.kettle syard.co.uk/wpcontent/uploads/2014/12/ onn_jones.pdf (accessed 9 May 2019).

Massumi, B. (2015) Politics of Affect. Cambridge: Polity Press.

OCR (2019) Exemplar Candidate Work, Art and Design (online). Available at: https:// www.ocr.org.uk/Images/461332-exemplarcandidate-work-gcse-art-and-design.pdf (accessed 9 May 2019).

Patai, D. (1992) Minority status and the stigma of 'surplus visibility', Education Digest, Vol. 57, No. 5, pp. 35-7.

Renold, E. \& Ringrose, J. (2017) Pin-balling and boners: the posthuman phallus and intra- activist sexuality assemblages in secondary school, in L. Allen \& M. L. Rasmussen, The Palgrave Handbook of Sexuality Education. London: Palgrave Macmillan, pp. 631-53.

Richardson, J. (2017) Folding pedagogy: thinking between spaces, in J. Jagodzinski [Ed.] What is Art Education? New York: Springer Nature, pp. 93-109.

Rubin, G. (1993) Thinking sex: notes for a radical theory of the politics of sexuality, in H. Abelove, M. A. Barale \& D. M. Halperin [Eds] The Lesbian and Gay Studies Reader. New York: Routledge, pp. 3-44.

Stanley, N. (2007) Preface: 'anything you can do': proposals for lesbian and gay art education, International Journal of Art \& Design Education, Vol. 26, No. 1, pp. 2-9.

Walker, D. (2007) Out there? Looking for lesbians in British art - some preliminary observations, International Journal of Art \& Design Education, Vol. 26, No. 1, pp. 89-97. 